(昭和 43 年 9 月 11 日受理)

再生セルロースフィルムにおけるセルロース II

結晶の面配向について

福井大学工学部高楿 利 禎

\title{
STUDIES ON THE SELECTIVE UNIPLANAR ORIENTATION OF (101) PLANES OF CELLULOSE II CRYSTALS IN REGENERATED CELLULOSE FILMS
}

\author{
By Toshisada Takahashi \\ (Faculty of Engineering, Fukui University, Fukui City, Fukui Prefecture, Japan)
}

It is well known that b-axes of cellulose II crystals tend to orient parallel to a drawing direction, and (101) planes prefer to orient perpendicular to a direction in which a bulk dimension decreases on rolling. However, in most literatures the former orientation (classified as uniaxial orientation) has only been concerned in relation to mechanical properties, spinning conditions and anisotropic swelling behaviors of regenerated cellulose fibers, though the latter orientation (classified as selective uniplanar orientation) could have also the important role. It is, therefore, interesting to make further investigations on these problems, putting the emphersis on the selective uniplanar orientation of (101) planes and its relation to the bulk properties.

In this paper, the first one of the series, the selective uniplanar orientation of (101) planes is studied in relation to coagulation and regeneration conditions, and then the explanation of the anisotropic swelling of flims is given in these terms.

The dominant selective uniplanar orientation of (101) planes is found for the films which are regenerated from viscose in regeneration bath containing a large amount of salt. The degree of orientation depends significantly on the concentration of sulfate. The lower the degree of swelling of fresh cellulose films are, the higher degree of orientation the dried cellulose films have. These results may be explained in the way that the orientation in this case is forced by osmotic compression, accompanied by dehydration normal to the film surface during the coagulation and regeneration process, which is different from the current explanation ascribing it to mechanical compression.

The cellulose films, in which (101) planes of cellulose II crystals orient parallel to the film surface, exhibit higher swelling and shrinkage in thickness. These behaviors may be explained on the basis of the distribution of hydroxyl groups in material. Because most hydroxyl groups locate on (101) surfaces of cellulose crystallite, these surfaces are hydrophilic, and water may permeate between them in the similar way that water may permeate between hydrophilic groups in soap micells.

It may be concluded from the results of $x$-ray investigations that the orientation of (101) planes takes place during the coagulation and regeneration process and not during the drying process.

(Received September 11, 1968)

1. 緒 言

ビスュース法再生㵶維恃，その紡㐘条珄によって製品 の性能がいちじてく巽なる。これを解明するため行
なわれたのが，織維形成機桠に関する研究であり，1930 年台にその端緒がひらかれた。ます Preston"は，スキ ンおよびョアと彼が名つけた密度および配列度のことな る組織をビスコースレーヨンに見出し，これを紡系時の 
流力学的配向にもとつくくものとした。これに対し小林2) らは組織形成の要因を紡浴とビスコースの相互作用に㷌 し、リーゼガング現象の一種であることを明らかにし た。

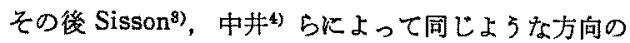
研究が詳紐に行なわれたが，まだ事実の説明に不充分な

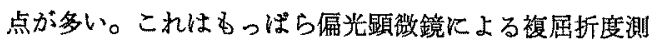
定のみに頼り，絨維素分子を回転棈円体として近似して 扱ったからであり，以下にのべるような纎維素分子のこ となる 2 万向に沽る性質のいちじるしい相違方無視さ れてきたためと考光られる。このため，膨潤現象のよう に水酸基と結びつけられるべき珄質炕ついては，きわめ て分弱な説明しか与克られていない。

セルロース瀻維においては単なるミせルの絨維軸配向 のほが，結晶面の配向も本留的意義をもつるの之考克 られるので，以下の研究を行なった。この報告では，ま ずフィルムに関しその面配向の生ずる現象を紡系条件と 照合しつつ追求し，さらに面配向性と膨潤初上び収縮の 異方性について検討した結果を報告する。

\section{2. 実 験 方 法}

\section{$2 \cdot 1$ 試 料調 製}

ガラス板上に厚さ $0.5 \mathrm{~mm}$ の塩化ビニールの枠を和き $\gamma$ 価 40 のビスコースを均一に㳊布し，枠をとりはずし た後，それそれの浴中で自由収縮状態で凝固再生し，水 洗後自由収縮状態で風乾する。

\section{$2 \cdot 2 \times$ 糡回折}

フィルム面をX線に対し平行になるように調整し、フ ルルム面のゴニオメータ軸要かりの回転 $\theta$ K対し, 計数

管を $2 \theta$ 回䎐させて, 回折 強度を測定した。この測定法 を以下反射法と称するが、フ ィルム面に平行に配向してい る結晶面 [(101) 面] からの $\mathrm{X}$ 線回折強度が計数されるが （101）面とほ济垂直な結晶面 [(101)面, (002)面]は Bragg 条件を满足しないので計数さ れない。次にX線に対しフィ ルム面を垂直に調整し同じょ， らにして测定した。この方法・” を以下透過法と称するが，こ の方法では、フィルム面に垂 直な結晶面からの回折 $\mathrm{X}$ 線が 計数されるが，フィルムに平 行な結晶面は Bragg 条件を
满足しないので計数されない。

反射法で克たX線回折强度曲線 の $2 \theta=12^{\circ}, 2 \theta=21^{\circ}$ 付近のピークの谷間をなめらかな曲線でつなぎ，(101) 面と $[(10 \overline{1})+(002)]$ 面の強度 $I_{(101)}$ と $I_{(10 \overline{1})+(002)}$ を求 めた。これから

$$
\frac{I_{(10 \overline{1})}-I_{(101)+(002)} \times \frac{i_{(101)}}{i_{(10 \overline{1})+(002)}}}{I_{(101)}}
$$

を面配向性のパラメータとして求めた。 $i_{(101)}$ はランダ 么配向試料の (101) 面の回折強度, $i_{(10 \overline{1})+(002)}$ はやはり ランダム配向試料の $[(10 \overline{1})+(002)]$ 面の回折強度であ る。その比は (101) 面と $[(10 \overline{1})+(002)]$ 面の構造因子 の違いを修正する值で面配向度を0から1の間の犆で評 価するためかけた值である。ランダム配向試料としては $\mathrm{H}_{2} \mathrm{SO}_{4} 50 \mathrm{~g} / /$ の浴中で再生して党たフィルムを用いた。 ランダム配向試料では $I(10 \overline{1})+(002) \times\left[i_{(10 \overline{1})} / i_{(101)}+(002)\right]$ は $I_{(101)}$ と等しくなり，面配向度は 0 ，また完全に平行に 面が配向した試料では $I_{(101)+(002)}$ は0であるから面配向 度は 1 となる。

\section{$2 \cdot 3$ 膨䦎之収縮の異方性}

一边の長さと厚さ既知の正方形のビスコース膜から出 発し，ビスニース

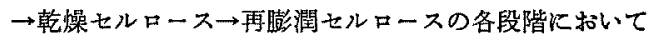
フィルムの面筫と厚さの変化を測定した。

\section{4 含水率の測定}

乾燥未経験のフレッシニセルロースの表面に付着して いる水を沪紙でとり除いたあとの重量と，105ㅇ 3 時間 乾燥後の重量比をもって含水率とした。

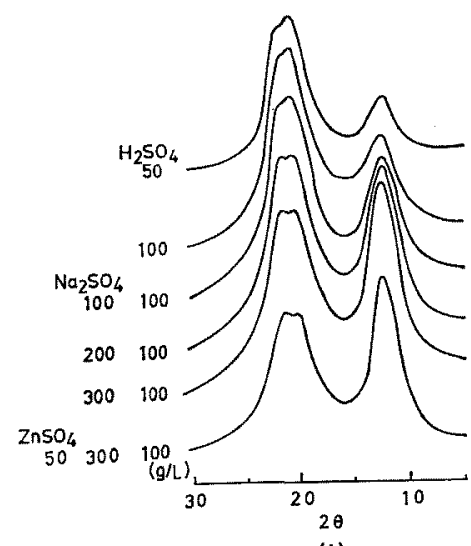

(1)

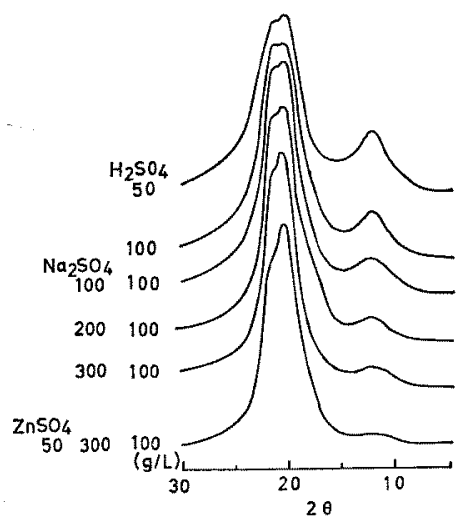

(2)

Fig. 1. X-ray diffraction patterns of cellulose films as a function of the composition of regeneration baths.

(1) Reflection method (2) Transmisson method 


\section{3. 実験結果と考察}

\section{$3 \cdot 1$ 同時凝固再生フィルムにおける面配向と膨潤お よび収縮挙動}

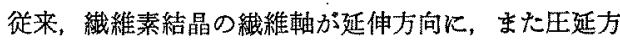
向に直角に（101）面が配向することが知られている5゙。 実験の結果，(101）面が機械的力によらずュロイド化学 的力たけによっても面配向することがわかった。ます硫 酸浴，(硫酸十ボウ硝) 浴，ミューラー浴を用いて凝固と 再生を同時に行なってえたフィルムについて検討した結 果についてのへる。主な試料関し，反射法と透過法に よるX楾回折強度曲線を第 1 因に，またフィルムの面配 向度と含水率の関係を第 2 図に示す。

(i) 硫酸単浴

硫酸濃度の低い場合，酸のフィルム中へのまたアルカ リ，水のフィルム外への相互拡散はゆるやかに行なわ

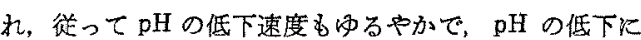
ともなうザンテートの溶解度の減少によっておこる脱水 凝固の程度の少ない段階でザントゲン基の分解が括こ。 て組織が完成されてしま5。この上らな条件の下では， 今子鎖の5ける compression は少なく，含水率(膨潤 度）の高い異方性の低いフレッシュヒルャースがえられ る。このよ5なフレッシュセルロースを自由収縮状態で 乾燥してす面配向度は向上好ず，乾爆後のフィルムの異 方性名低小（第 1 図）。

硫酸濃度を上げると，比較的急速な脱水と $\mathrm{H}^{+}$自身の 凝固能の增大にともない，脱水凝固程度のやや高い状態

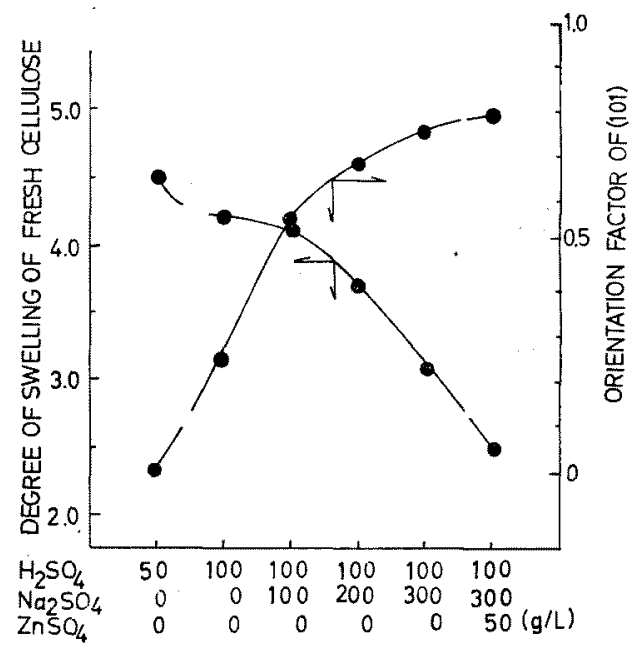

Fig. 2. Degree of swelling of fresh cellulose films and orientation factor of (101) planes of dried cellulose films prepared in different regeneration baths.
で組織が固定され面配向性のやや高いフィルムを5る。 しかしいずれにしてる，硫酸単浴の場合は面配向珄は低 w。

(ii) (硫酸十ボウ硝) 浴

ボウ硝濃度を高くしてゆくと，第 1 図，第 2 図のよ5 に,フレッシニセルロースの含水率とフィルム内の結晶 の配向性にいちじるしい変化があらわれる。ボウ硝 200 $g / l$ ，付近から面配向性は急に高くなるが，これは含水率 の急に低下しはじめるボウ硝濃度と一致して招り，浴の 脱水能力と面配向珄とが密接な関係にあることを示す。 ボウ硝濃度が増大すると，その速い脱水凝固速度によっ て， $\mathrm{H}^{+}$によるザントゲン基の分解，すなるち組織の固 定の前にビスコースフィルムは充分脱水されることにな る。しかも $\mathrm{Na}^{+}$は $\mathrm{H}^{+}$と共存すると， $\mathrm{H}^{+}$の作用を抑 制寸ることが堀尾泉によって見出されて特り，上記の脱 水はすすす效果的に行なわれる。脱水方向はフィルム

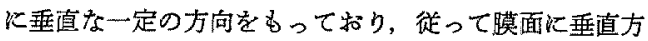
向に compression が作用し，その結果 (101) 面で瞙面 に平行に配向してくることになる。

面配向性の高いフィルムと低いフィルムとでは，ビス コースーフレッシュセルロースー乾燥セルロースの収縮

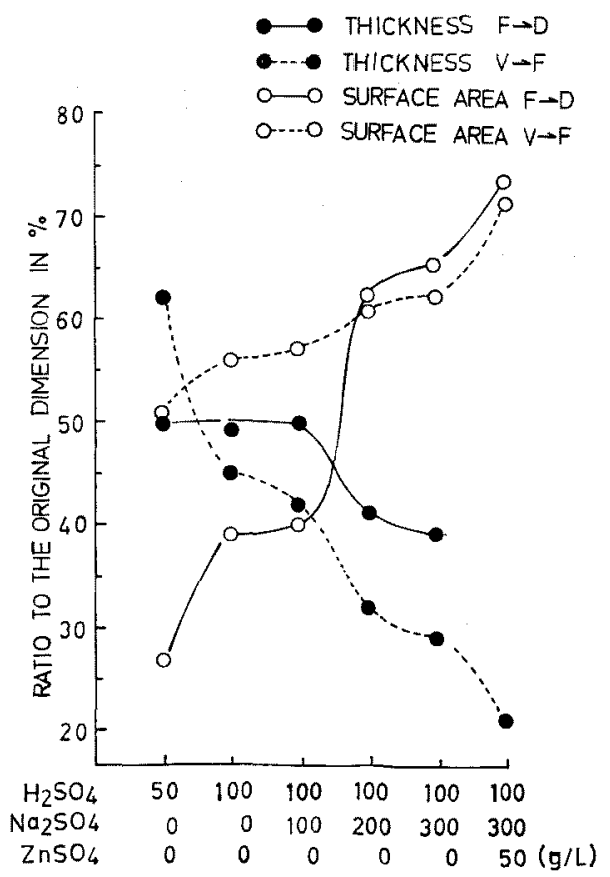

Fig. 3. Contraction of thickness and area of coagulation and drying.

V : Viscose, F : Fresh cellulose, D : Dried cellulose 


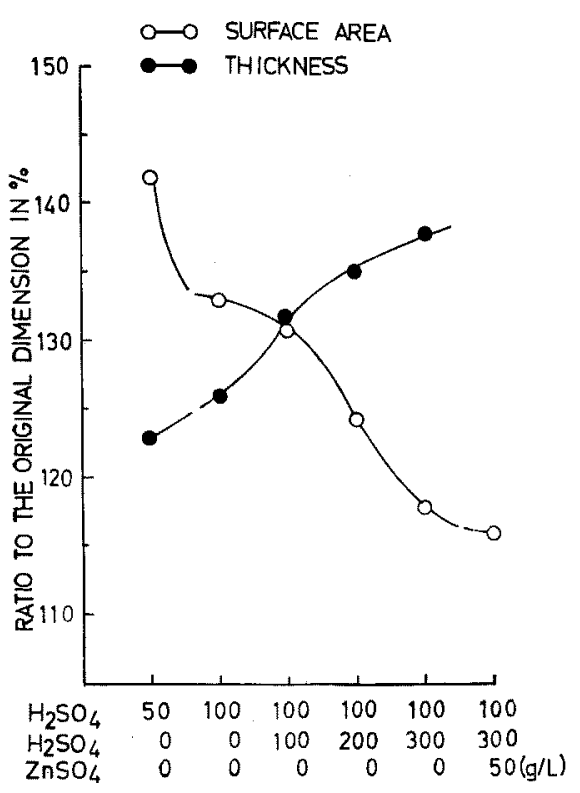

Fig. 4. Increase in thickness and area with swelling for cellulose films prepared in different regeneration baths.

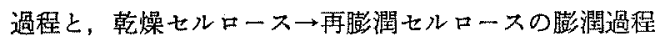
での挙動がいらじるしく翼なる。第 3 図は收縮過程に括 ける面積と厚さの収縮挙動を示するのであり，ボウ硝の 共存量の多い浴で再生した面配向性の高いつィルム活ど,

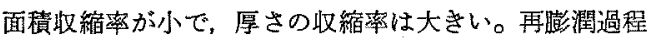
では第 4 图の上5 に面配向性の高いフィルム浪と，面積 膨潤率小で厚さの膨潤率は大となる。

せルロースの吸湿現象や膨潤現象は, 多くの昜合非晶 㴿域にもとづいて説明されてきた。最近高原ら゙もせ口 ハンの翼方性膨灌現象全複屈折加ら結晶領域による 寄与を差引くことによってえた非晶セグメントの面内配 向度とその膨潤異方性によって説明した。この機構は，膨 潤炕より非晶セグメントの配向性は乱れてくることや, せルロースセグメントに水和できる水の量る限られてい ることより，低い吸水率の籁囲内に限られよう。しかし 面配向した乾燥末経験のフィルムでは 200 300\% の水 が注とんど厚さ方向に分布している現象や，再膨潤の場 合も $100 \%$ 程度の水が注とんと厚さ方向に浸入してくる などの現象のよろK，非晶セグメントだけで性説明の難 かしい現象もある。

ところでX線非晶性散乱は，パラクリスタルのひずみ としても解释されることは，今日一般的に受け入れられ ているが，非晶セグメントが存在するとしてもその面内 配向性孫低いすすなわら (101) 面の面配向したフィルム
(1)

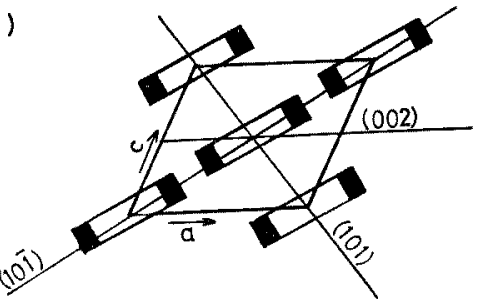

(2) FILM SURFACE

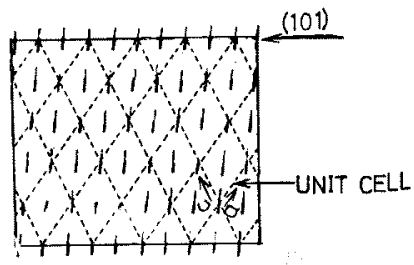

Fig. 5. Unit cell and crystallite of cellulose II

(1) Unit cell of cellulose II and arrangement of molecules in it.

(2) Cross-section of cellulose II crystallite, whose (101) plane orients parallel to film surface.

に平行にX線を入射してらるX楾図をみても，非晶性散 乱の配向性はみとめられない。高原らもX線的な非晶性 散乱の分布がランダムであることをみとめている（ただ しこれは非晶せグメントの配向とは無関係としている)。 桜田らも延伸ポリビニルアルコールの非晶性散乱が方位 角に依存しないことを観測している。われわれの場合 も，X線的には非晶セグメントは面内で無配向であると してよいと考える。そこで次のような点を考察してみ る。

1.4 グルコシッド結合によって連結された 2 個の椅子 形の $\beta$ ダルニース基をうすい板と考克ると，炭菜原子 と結合している水素原子はその上下に突き出して敌り，

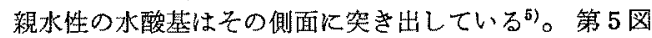
（1）のセルロース(II)の単位胞に乱いて分子鎖の両側面 の黒い部分は水酸基を含む親水性の領域である。第 5 図 (2)の微結晶の断面に抋いて単位胞を図の上う配置す ると，結局微結晶の（101）表面水酸基が集中すること になりこの上下の面は，他の両儧面に比較すると親水 性であると考えてよい。脱水力の強い浴で㠜固再生した フィルムでは，(101）面がうィルム表面に平行に配向乙 ているが，この状態で水は対向する微結晶の (101) 面の 間に残存していることになる。その結果，面配向性の高 いフィルムの乾燥時の厚さ方向の収縮率は大となる。一 方 [(101) +(002)] 面間には水が保持されず面皘収縮率 
FILM SURFACE

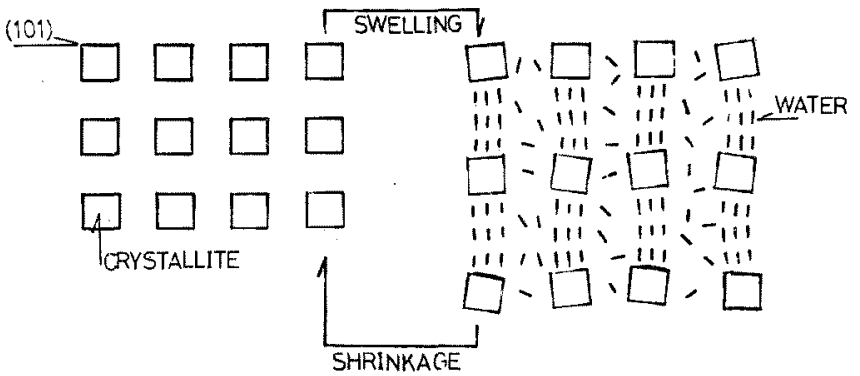

Fig. 6. Schematic representation of reversible swelling and shrinkage process of regenerated cellulose film having selective uniplanar orientation of (101) planes along film surface.

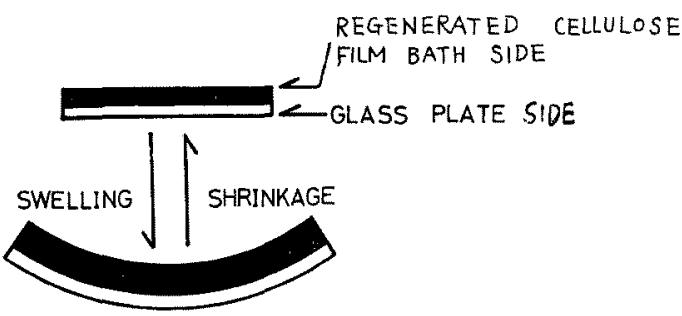

Fig. 7. Curling of cellulose film regenerated on glass plate in the bath containing mush salt.

は小さい。再膨潤およびその後の収縮挙動む同じように 説明される。(101）面は水に対し鋭敏であるので，水に 浸せきすることにより，セルマース結晶は（101）面に垂 固な万向で裂開され水に押しひろげられる。結果として 水は微結晶の (101) 面の間に入りやすくなるので, 面配 向性の大なるフィルムの厚さ力向の膨潤率と收縮膟は大 となる。第 6 図はこの過程をモデル的に示したものであ る。当然のことであるが，䁗潤率と取縮率にいらじるし い変化の呿こりはじめる時の共存する硫酸ソーダの濃度 は，含水率と面配向度にいちじるしい変化の叔こはじ める濃度とよく一致している。

乾學経歌のない高膨潤フレッシェセルロースは，自己 の数倍の水を包含している場合がある。いわゆる非晶領 域がこの上うな大量の水を吸収して膨潤できるかどうか 疑問な点がある。また包含されている水が汪とんど自由 水であるならば，そのフィルム内の分概は三次元的にラ ンダムなはずであり，乾䍘によってこの水が放出される ならばフィルムは等方的に収縮しなければならない。し かし大睤の水はその大部分が厚さ方向飞分布して沶り， 結晶の (101) 面間に棈造化されて保持されていると考兄

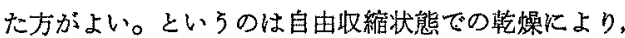
大量の水が放出されるにもかかからず，フレッシニせル
ロースの面配向性が一層強くなること が次の項の実験で確かめられた。䓧端 にいらと，親水性基の突き出している 石けんミ七ルの表面に水分子方浸入し てくる現象に似ている。

面配向フィルムの膨潤お゙よび収縮の 巽方性と関連して次の琴象がある。第 7 図のようにカラス板上で直接再生し た面配向性の高いフィルムを乾燥後再 憉閏すると，再生浴側を中心にいちじ るしくカールする。 Sisson ${ }^{8)}$ と Morehead はこの現象蒙スキンを形成す るようなミューラー浴で再生したフィ ルムについて認められるとして，スキ

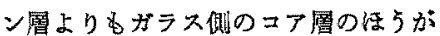
橵潤度の高いためであると説明している。しかしこ れは次のように説明されるべである。浴側の㳗 ががラス側よりる，脱水による compression 效果 を有效にうけて特り，面配向度の高いことは考党ら れることである。このフィルムを再膨潤与ると，浴 側のはうが厚さ瞦潤度が高く面積膨潤度が低い。方ガラス側はその逆であると洘克ると，フィルムは 浴側を内にしてカールすることになる。実際，いわ ゆるスキン層を形成するミューラー浴を使用しない です，フィルムは前述の面配向の程度に応じてカールす る。凝固後再生フィルムはどれるカールしない。

ビスコース㵶維のスキン畨の断面での非対称珄にもと ついて揬縮の発現を説明する場合も，単にスキンとコア の膨潤性の相違だけでなく，面配问性のことすあわせて 考虙する汪うが合理的である。

（iii）（硫酸十ポウ硝十硫酸亜鉛）浴・ミューラー浴

第 1 図と第 2 図のよ 5 に, 硫酸西鉛の添加によつて, （101）面の面配向性と膨潤执よび収縮の異方性は大きく なる。硫酸亚鉛の効果は，それ自体の凝固能によるもの と, ボウ硝との共存によりその凝固能を增大させる sensitizing action"), 要鉛ザンテートの形成により $\mathrm{H}^{+}$ による再生を革延させることによるものなどがある。こ れらの效果に上り，セルロースの再生の前に脱水が一層 強力に行なかれ，(101）面の選択的配向に対し compression がより効果的に作用する。ボウ硝の含采れない場 合は，硫酸再鉛浀度を高くしても面配向度は低い。

3.2 凝固後再生フィルムにおける面配向と膨閏およ び叹縮挙動

ボウ硝単浴蛙よび（ボウ硝十硫酸亜鉛）浴でじゅうふ んにゲル化後に再生したフィルムにおける面配向性を検 討した。第 8 図に，ポウ硝 $100 \mathrm{~g} / l$ ，ボウ硝 $300 \mathrm{~g} / l$ ，就 


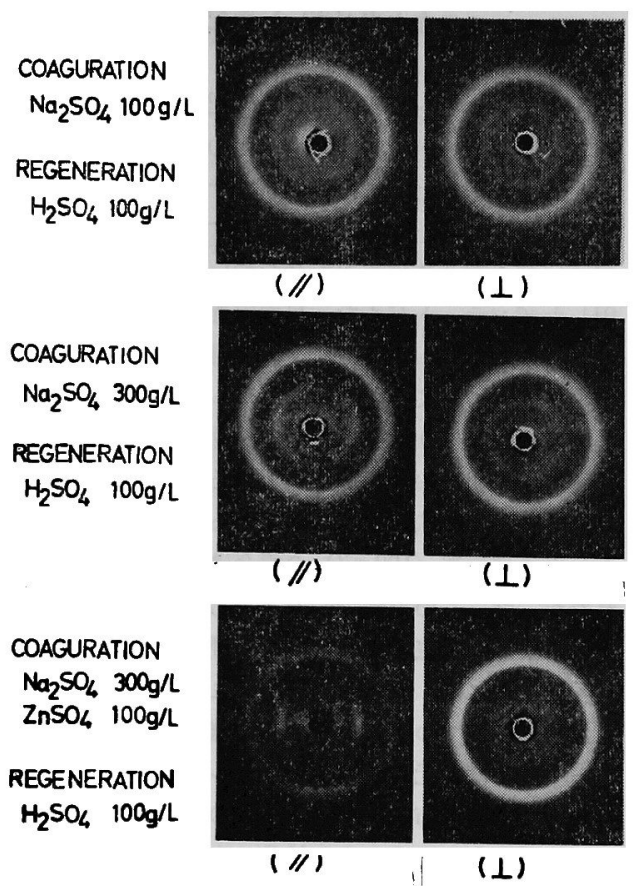

Fig. 8. X-ray diffraction patterns of cellulose films regenerated after coaguration.

(/I) X-ray beam parallel to the film surface.

(L) X-ray beam perpendicular to the film surface.

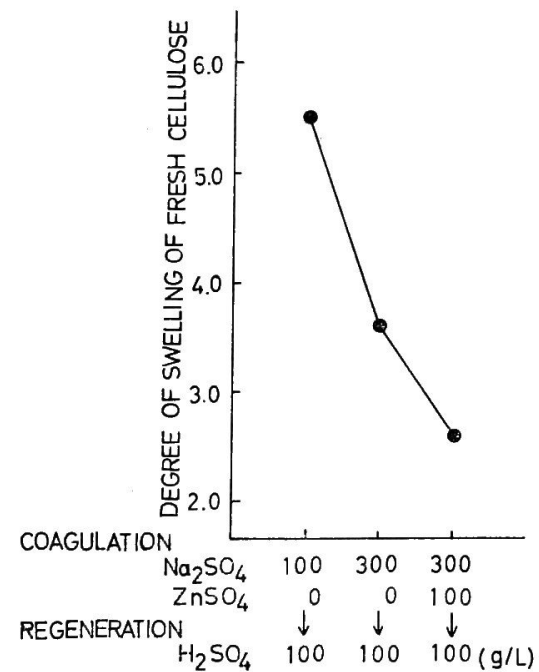

Fig. 9. Degree of the swelling of fresh cellulose films regenerated after coagulation.

ウ硝 $300 \mathrm{~g} / l+$ 硫酸亜鉛 $100 \mathrm{~g} / l$ で凝固後再生した乾燥 状態に拈けるX線図を，また第 9 図に含水率を示した。

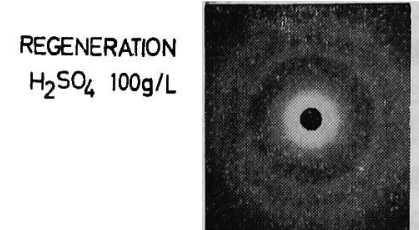

( /I)

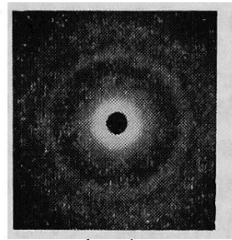

( II)

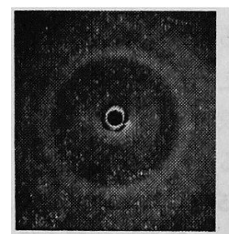

( /I)

REGENERATION $\mathrm{H}_{2} \mathrm{SO}_{4}, 100 \mathrm{~g} / \mathrm{L}$ $\mathrm{Na}_{2} \mathrm{SO}_{L} 300 \mathrm{~g} / \mathrm{L}$

REGENERATION $\mathrm{H}_{2} \mathrm{SO}_{4} 100 \mathrm{~g} / \mathrm{L}$ $\mathrm{Na}_{2} \mathrm{SO}_{L} 300 \mathrm{~g} / \mathrm{L}$ $\mathrm{ZnSO}_{4} 50 \mathrm{~g} / \mathrm{L}$

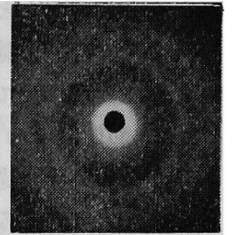

$(\perp)$

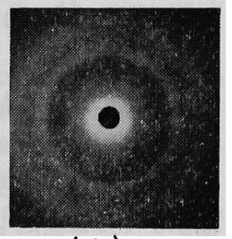

$(\perp)$

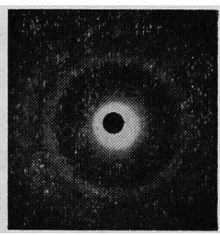

(ц)
Fig. 10. X-ray diffraction patterns of fresh cellulose films.

(//) X-ray beam parallel to film surface

( $\perp$ ) X-ray beam perpendicular to film surface

低い脱水能力しか持たない凝固浴（ボウ硝 $100 \mathrm{~g} / l$ ) で疑 固後再生したフレッシュフィルムの含水率は高く, 乾燥 後の面配向性は低い。ボウ硝濃度をますと面配向性が強 くなり，硫酸亜鉛を共存させるとその傾向はさらに強く なる。硫酸亜鉛単浴ではこのような高い面配向性はえら れず，ボウ硝と硫酸两鉛の強い相乗作用によって脱水能 力が増大していることがわかる。

P. H. Hermans ${ }^{10)}$ は, 凝固は秒のオーダでおこり相当 迅速な反応であるが，七ルロース分子鎖のよ5に大きい 分子のビスコース中の動きは非常にゆるやかであり, 凝 固後のザンテートゲルの構造は, るとのビスコースの構 造とあまりかわらず, 高濃度のしかも強力な脱水力を持 つ凝固浴から形成されたゲルもゾル状態の容積をほとん ど保持しているとのべている。しかし前述のように, 強 力な脱水力をもつ浴で㠜固後再生したセルロースの含水 率は相当低く, 容積娍少もいちじるしい。強力な脱水力 によって, ザンテートの結晶領域はその生長とともに （101）面が膜面に配向して行くのであり，ザンテートゲ ルはビスコース中の構造とは全く異なった構造をとって いる。

ビスコースーフレッシュセルロース 乾燥セルロース の過程に括ける収縮挙動および，再膨潤挙動は前述の同 
時凝固再生の場合と全く同じであり，面配向性の高い】 ィルムほど面積収縮率括よび膨潤率が低く，厚さ収縮率 および膨潤率は大である。

\section{3 面配向のおこる段階}

凝固過程，再生過程，乾燥過程でそれぞれ水が放出さ れるので，このどの段階で面配向が扣こっているのか検 討する必要がある。再生後末乾燥 フレッシュせルッー スのX線図を第 10 図に示す。硫酸 $100 \mathrm{~g} / \mathrm{l}$ の浴で再生 したフィルムでは，X線をつィルムに平行に入射した場 合も垂直に入射した場合も，(101）反射，(10ī+002)反 射とも Debye ring となっているが, ボウ硝と硫酸西鉛 を多量に含む浴で再生したフィルムでは, 明らかに(101) 面がフィルム面に平行に配向していることがわかる。第 10 図のX線図に打いて，2 $\theta=27^{\circ}$ 付近の強いハローは 水による散乱である。以上の結果から、フィルム内の微 結晶に面配向の与兄られるのは, ビスコースからフレッ シュセルロースの段階であることがわかる。乾燥過程は 単にそれを強調する過程にすぎない。フレッシュセルロ 一スの含水率は $2.5 \sim 4.5$ と相当高く，七ルロースの数 倍の水を含んでおり，最高の面配向性を示す場合でる， まだかなり乱れた状態にある。第6図のように面配向性 の高いフレッシュセルロースの場合，水は対向する水酸 基間（微結晶表面の）で情造化されて残存しており，西 との自由収縮状態での乾燥過程では，水の放出とともに 徽結晶の（101）面はますます対向してきて，面配向はか えって促進きれている。ビスュースからフレッシュセル ロースの過程で面配向の抗こっていない場合は，水はフ ィルム内にランダムに存在し, 乾燥過程では前者よりも か党って多量の水を放出するにもかかわらず(フレッシ

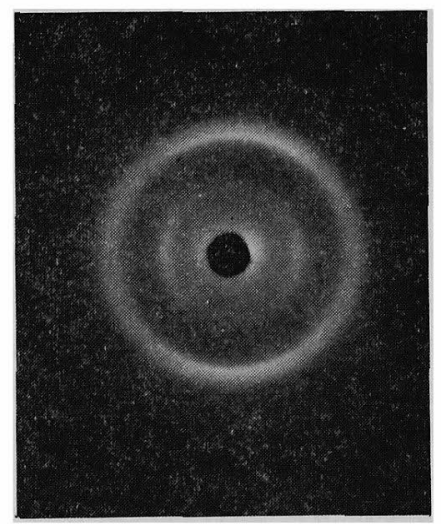

Fig. 11. X-ray diffraction pattern of cellulose film coagurated in a bath containing $\left(\mathrm{Na}_{2} \mathrm{SO}_{4} 300 \mathrm{~g} / l+\mathrm{ZnSO}_{4} 100 \mathrm{~g} / l\right)$, decomposed in hot air, treated with water and dried. X-ray beam parallel to film surface
ュセルロースの含水率が高い）面配向は乾燥過程では括 こらない。

次にザンテートダルに和ける面配向の現象についての ベる。3.2 でのべたように塩濃度の高い場合は明らかに 面配向性を示した。この場合ザンテートゲルの状態です で面配向しているかどうか倹討する必要がある。第11 図は，ボウ硝と硫酸覀鉛を含む強い脱水力をるつ浴で疑 固したザンテートゲルを，自由収縮状態で完全に空気中 で熱分解した後，水処理によって再結晶化したせルロー スフィルムに，X線を平行に入射した時のX 線図であ る。明らかに (101) 面の面配向が認められる。すなわち 翰燥フィルムにおいて抗こっている面配向は，すでにザ ンテートゲルの状態でおこっていることが確かめられ た。ボウ硝単浴 $(100 \mathrm{~g} / l)$ の場合は面配向性はみとめら れなかった。この実験で問題となること，すなわらザン テートゲルを空気中で熱分解する間に分子鎖凝集状態 や配向状態には，根本的変化のおこらないことは確かめ てある。後報でのべるように，空気中で熱分解したザン テート試料は，元のザンテートゲルと注とんど全く同じ $\mathrm{X}$ 線回折強度分布曲線を与光，この間の面配向性河何 かの影響をむたらすような結晶の生長や回転などの現象 は全く括こらない。すなわち空気中熱分解し，水処理し た試料のX線図は，ザンテートゲルに括ける「潜在的」 な面配向性を反映しているものと考兄てよい。この場合 亜鉛ザンテートダルが形成されているので，X線回折強 度が微弱となっていて，直接面配向性を確かめることは できなかった。

\section{4. 結論}

ビスコースから，同時凝固再生または凝固後再生した セルロースフィルムについて, 紡浴組成々面配向性の関 係，面配向性と膨潤収縮举動との関係について検討し， さらにこのような面配向がどの過程でおこるのか検討 し，次の結果をえた。

1. ビスコースからセルロースを再生する場合，硫酸 と共存する塩類濃度が高い場合には，機械的圧縮によら なくても単なる脱溶媒和力によって，七ルロース微結晶 の (101) 面か゚フィルム面に平行に配向する。

2. 塩類濃度の高いほどフレッシュセルロースの含水 率は小となり，面配向度は高い。

3. 面配向度の高いフィルムは, 厚さの憉潤率および 収縮率が大きく，面積収縮率扣よび膨潤率が小となる。 この現象は, 微結晶の (101) 面が親水性であり, 水がこ の間に入ってくるものとして説明される。

4. じゅ5ぶん凝固した後で再生したフィルムについ ても，同時凝固再生の場合と同じ現象がみとめられた。 
5. そルロース微結晶の面配向は，同時凝固再生の場 合はフレッシュヒルロース状態ですでにおこっているこ とを，膨潤状態のままのX線図を学て確認した。また凝 固後再生フィルムの場合には，塩濃度の高い浴で凝固し たザンテートゲルにおいて，すでに面配向が潜在的に蛒 こっていることを間接的ではあるが確かめた。

付記 この研究は, オーミケンシ株式会社の瓜遗研究 生として, 京都大学工学部高分子化学教室堀尾研究室に 抋いて行なったるので，終始ご指導ご鞭撻をいただいた 㻕尾正雄教授，小林恵之助教授ならびにオーミケンシ株

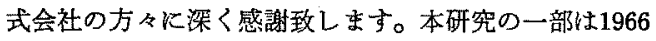
年国際高分子学会（京都）で発表した。

文献

1) J.M. Preston ; J.Soc. Chem. Ind., 50, T 199
(1939)

2) M. Horio, K. Kobayashi, K. Kondo; Text. Res.. $J ., 17,264(1947)$

3) F.F. Morehead, W.A.Sisson ; Text. Res. J., 15, 443 (1945)

4) 中井章能; 䋳学誌, 15, 703, 708 (1959)

5) P. H. Hermans; Physics and Chemistry of Cellulose Fibers p. 11 (1949)

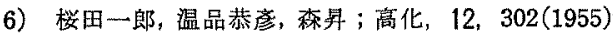

7) H. Takahara, S. Nomura, H. Kawai, Y. Yamaguchi, K. Okazaki and A. Fukushima ; J. Polymer Sci., A-2, 6, 197 (1968)

8) W. A. Sisson; J.Phys. Chem., 44, 513 (1940),

9) M.Horio; Text. Res. J., 20, 373 (1950)

10) P.H.Hermans ; Physics and Chemistry of Cellulose Fibers p. 376 (1949) 